\title{
A Toxicological and Phytochemical Study on the Iran's Ecballium elaterium (L.) A. Rich.
}

\author{
Kianbakht S (Ph.D.) ${ }^{1 *}$, Ziaee M (Ph.D.) ${ }^{2}$, Momtaz S (Ph.D.) ${ }^{1,3}$, Hajiaghaee R (Ph.D.) ${ }^{1}$ \\ 1- Medicinal Plants Research Center, Institute of Medicinal Plants, ACECR, Karaj, Iran \\ 2- Medicinal Plants Research Center, Maragheh University of Medical Sciences, \\ Maragheh, Iran \\ 3- Toxicology and Diseases Group, the Institute of Pharmaceutical Sciences (TIPS), \\ Tehran University of Medical Sciences, Tehran, Iran \\ *Corresponding author: Institute of Medicinal Plants, Research Complex of Iranian \\ Academic Center for Education, Culture and Research (ACECR), ACECR Street, \\ Exit of the Baharestan Industrial Town, 55 $5^{\text {th }}$ Kilometer of Tehran-Gazvin Freeway, \\ Pouleh Kordan, P.O.Box (Mehr Villa): 31375-369, Karaj, Iran \\ Tel: +98-2634764010-9, Fax: +98-2634764021 \\ E-mail: skianbakht@yahoo.com
}

Received: 24 Oct. 2018

Accepted: 14 Jan. 2019 doi: 10.29252/jmp.3.71.67

\begin{abstract}
Background: Ecballium elaterium is endemic to the northwestern Iran and its fruit is traditionally used for therapeutic purposes in Iran. The toxicological and phytochemical characteristics of the Iran's Ecballium elaterium have not been investigated so far.

Objective: Study on some toxicological and phytochemical features of the Iran's Ecballium elaterium fruit $90 \%$ ethanol extract.

Method: The antioxidant capacity in the DPPH (2,2-diphenyl-1-picrylhydrazyl) assay and total phenol and flavonoid contents were determined by spectrophotometry. The rutin (phytomyelin) content was measured by HPLC. Moreover, oral and intra-peritoneal LD $_{50}$ (median lethal dose) after 72 hours of the extract administration in rat were determined by the graphical method of Miller and Tainter. The cytotoxicity against several cancer and non-cancer cell lines was determined by the MTT (mitochondrial tetrazolium) method.

Results: The $\mathrm{IC}_{50}$ (inhibitory concentration 50\%) in the DPPH assay was $3.57 \pm 0.006 \mathrm{mg} / \mathrm{mL}$. The total phenol in terms of $\mathbf{m g}$ Gallic acid/0.05 g extract was $17.84 \pm 0.92$. The total flavonoid in terms of $\mathrm{mg}$ rutin/ $/ 0.1 \mathrm{~g}$ extract was $33.35 \pm 1.06$. The extract contained $1 \mathrm{mg} / \mathrm{g}$ rutin. The oral and intraperitoneal $L D_{50}$ of the extract were $472 \mathrm{mg} / \mathrm{kg}$ and $425 \mathrm{mg} / \mathrm{kg}$ respectively. The extract showed strong cytotoxicity in ACHN and ASPC1 cell lines, which was followed by Caco2 and PC12 cells. Non-neoplastic cells were much less affected by the extract in comparison with the cancerous cells. Conclusion: The extract has low antioxidant activity. The oral and intra-peritoneal toxicities of the extract in the $\mathrm{LD}_{50}$ test are moderate. The extract has considerable selective toxicity against cancer cells.
\end{abstract}

Keywords: Ecballium elaterium, Phytochemistry, Toxicity, Toxicology 


\section{Introduction}

Ecballium elaterium (L.) A. Rich. (E. elaterium) (squirting or wild cucumber) is a perennial vine of the Cucurbitaceae family endemic to the Mediterranean region including the Azarbaijan and Guilan provinces of Iran [1]. In the areas where the plant grows, its fruit is traditionally used orally and topically for the treatment of various diseases such as sinusitis, fever, cancer, hepatic diseases, jaundice, constipation, hypertension, edema, rheumatic diseases and fungous infections [1-3]. Pharmacological studies have demonstrated that the plant's fruit has anticancer [4-6], antibacterial [3], antifungal [3], analgesic [7], antipyretic [7], anti-inflammatory [8], positive inotropic [9], hepatoprotective [10], blood bilirubin reducing [11], anti-leukemic [12] and anti-sinusitis [13, 14] effects, among others. The plant contains many bioactive compounds including phenols, flavonoids such as rutin (phytomelin) and triterpenoids (cucurbitacins) [15]. All parts of the plant especially fruits are considered as toxic [16]. Toxic and allergic reactions and even death in humans due to the use of the plant's fruit have been reported [16]. Considering the pharmacological effects and traditional uses of the plant, it is a potential source for development of new therapeutic agents [17]. However, little research regarding the plant's toxicity has been conducted. Moreover, the biological effects including toxicity and phytochemical characteristics of the Iran's E. elaterium have not been evaluated so far. Therefore, some toxicological and phytochemical parameters of the Iran's E. elaterium were investigated in the present study.

\section{Materials and Methods}

\section{Plant collection}

The fruits of E. elaterium were collected from the Moghan region of the Iran's Ardebil Province in July 2017 and a voucher specimen of the plant (number 5238) was deposited in the Central Herbarium of the Tabriz University (Iran).

\section{Plant extraction}

The plant fruits were dried, powdered (100 g) and macerated with a $90 \%$ ethanol solution for 3 days with three changes of the solution. The resulting extract was filtered and evaporated under vacuum into a dried powder extract. Then, the extract was dissolved in methanol and filtered through $0.45 \mu$ membrane filter (Millipore), and injected directly for HPLC analysis.

\section{Determination of the extract total phenolic content}

The total phenolic content was determined by the Folin-Ciocalteu colorimetric method according to a modification of the procedure described by Obanda [18]. In this method, the plant extract solution ( $1 \mathrm{~mL}$ ) was diluted with 5 $\mathrm{mL}$ distilled water and mixed with $500 \mu \mathrm{L}$ of the Folin-Ciocalteu reagent in a volumetric flask. $1 \mathrm{~mL}$ of $15 \%$ sodium carbonate solution was added to the mixture and allowed to stand for $30 \mathrm{~min}$. Then, the absorbance was determined at $725 \mathrm{~nm}$ using a spectrophotometer (Human, USA). Gallic acid was used as standard to produce the calibration curve. The total phenolic content was expressed as $\mathrm{mg}$ of gallic acid equivalents per $100 \mathrm{~g}$ of 
extract. All samples were analyzed in triplicates.

\section{Determination of the extract total flavonoid content}

Total flavonoid content was estimated by aluminum chloride colorimetric assay [19]. 1 $\mathrm{ml}$ of extract and standard solution of rutin (250, 500, 750, 1000 and $1250 \mathrm{mg} / \mathrm{L})$ was added to $10 \mathrm{~mL}$ volumetric flask, containing 4 $\mathrm{mL}$ of distilled deionized water $\left(\mathrm{dd}_{2} \mathrm{O}\right)$. After $5 \mathrm{~min}, 0.3 \mathrm{~mL} 10 \% \mathrm{AlCl}_{3}$ was added and the total volume was made up to $10 \mathrm{~mL}$ with $\mathrm{dd}$ $\mathrm{H}_{2} \mathrm{O}$. The solution was mixed well and the absorbance was calculated against prepared reagent blank at $420 \mathrm{~nm}$ with a UV-Vis spectrophotometer. Data of total flavonoid content of dry extract was expressed as milligrams of rutin equivalents $(\mathrm{Ru})$ per $0.1 \mathrm{~g}$ dry extract (mg Ru/0.1 g extract). All samples were analyzed in triplicates.

\section{DPPH (2, 2- diphenyl - 1 - picrylhydrazyl) assay of the extract}

The DPPH test was used to estimate the antioxidant capacity of the extract [20]. $1 \mathrm{ml}$ of various concentrations $(250,125,62.5,31.25$, 15.62 and $7.81 \mu \mathrm{g} / \mathrm{mL}$ ) of the extract in ethanol was added to $4 \mathrm{~mL}$ of $0.004 \%$ methanol solution of DPPH. After a 60 min incubation stage at room temperature, the absorbance was read against a blank at $517 \mathrm{~nm}$. Inhibition of free radical by DPPH in percent (I \%) was calculated in following way:

$$
I \%=\left[\frac{\text { A blank }- \text { A sample }}{A \text { blank }}\right] * 100
$$

A blank =Absorbance of the control solution (containing all reagents except the test extract).

A sample =Absorbance of the test extract.

Extract concentration providing 50\% inhibition $\left(\mathrm{IC}_{50} \%\right)$ was calculated from the graph of percent inhibition against extract concentration. $\mathrm{IC}_{50} \%$ values were compared to $\mathrm{IC}_{50} \%$ value of a "standard" antioxidant, in this case ascorbic acid, obtained by the same procedure.

\section{Determination of the extract rutin content Preparation of standard solutions}

$10.0 \mathrm{mg}$ of rutin was dissolved in $2 \mathrm{~mL}$ of methanol and diluted to $10.0 \mathrm{~mL}$ with $50 \%$ methanol. Also, $2 \mathrm{~mL}$ of this was diluted to 10 and $100 \mathrm{~mL}$ with $50 \%$ methanol. All sample solutions were filtered through $0.45 \mu$ membrane filter (Millipore), and injected directly [15].

\section{HPLC Analysis}

The HPLC system was a Waters 600E with a UV-Vis detector (Waters 486) and a $50 \mu \mathrm{L}$ sample loop. A discovery reversed phase YMC Triart-C18 (250 mm×4.6 mm i.d., particle size $5 \mu \mathrm{m}$ ) column was used. The mobile phase consisted of water with $1 \%$ glacial acetic acid (solvent A), and methanol (solvent B). The gradient was used for determination of rutin in the extract [15] with some modifications: $68 \% \mathrm{~A} / 32 \% \mathrm{~B}, 0-5 \mathrm{~min} ; 50 \% \mathrm{~A} / 50 \% \mathrm{~B}, 5-20$ $\min ; 100 \% \mathrm{~B}, 20-35 \mathrm{~min}$. The flow rate was 1.3 $\mathrm{mL} / \mathrm{min}$, and the injection volume was $20 \mu \mathrm{L}$. The monitoring wavelength was $350 \mathrm{~nm}$. 
A Toxicological and ...

\section{Quantitative determination}

Calibration curve of rutin was obtained by triplicate measurements on methanolic solutions of the standard at increasing concentration. The calibration curve was found by using the simple equation:

$\mathrm{A}=\mathrm{mC}+\mathrm{b}$

Where $\mathrm{C}$ is the rutin concentration and $\mathrm{A}$ is the peak area, calculated by HPLC software.

\section{Evaluation of the extract toxicity in rat}

Different doses of the extract dissolved in normal saline were gavaged or intraperitonellay injected once to groups each consisting of 10 rats (5 males and 5 females) in a volume of 5 $\mathrm{mL} / \mathrm{kg}$. Then, the numbers of dead animals within $72 \mathrm{~h}$ after gavage or intraperitoneal injection were counted and $\mathrm{LD}_{50}$ was calculated according to the graphical method of Miller and Tainter described previously [21, 22]. The extract doses were 5, 25, 50, 100, 250, 500, 750, 1000,3000 and $5000 \mathrm{mg} / \mathrm{kg}$.

\section{Evaluation of the extract cytotoxicity in vitro}

Caco-2 (colon adenocarcinoma), ACHN (renal adenocarcinoma), ASPC1 (pancreas adenocarcinoma) and PC12 (pheochromocytoma), and NIH3T3 (Swiss mouse embryo fibroblast) were obtained from Pasteur Institute of Iran (Tehran, Iran). RPMI (Roswell Park Memorial Institute medium) 1640, DMEM (Dulbecco's Modified Eagle's medium) and FBS (fetal bovine serum) were purchased from Biosera (UK). Pen-strep and trypsin- EDTA were purchased from Gibco (UK). MTT (3-[4, 5-dimethylthiazol-2-yl] 2, 5diphenyl tetrazolium bromide) was purchased from sigma (Germany).
Mitochondrial tetrazolium test (MTT) assay (23) was conducted to assess the viability of NIH3T3, ACHN, ASPC1, Caco2 and PC12 against various concentrations of the extract. The above-mentioned cell lines were maintained as exponentially growing cultures in either DMEM or RPMI 1640 cell culture medium supplemented with $10-15 \%$ FBS and antibiotics, under culture conditions. The plant extract was used at concentrations ranging from 1.953-1000 $\mu \mathrm{g} / \mathrm{mL}$ doubling dilutions, and the cells were incubated for 24,48 and 72 h. By $24 \mathrm{~h}$ intervals, cells were treated by MTT solution $(5 \mathrm{mg} / \mathrm{mL})$ and the absorbance was measured. Each experiment was performed in 4 repetitions and cells with no treatment were considered as control. The concentration required for $50 \%$ inhibition of cell viability $\left(\mathrm{IC}_{50}\right)$ were determined by a nonlinear regression analysis and expressed in mean \pm standard error of mean (SEM).

\section{Statistical analysis}

Statistical differences between treated and control groups were examined by one-way analysis of variance followed by Turkey's tests (Stats-Direct version 3.1.18). Difference was considered statistically significant at $\mathrm{P}<0.05$.

\section{Results}

\section{Phenolic and flavonoid contents}

The total phenolic compounds of the extract with gallic acid as standard and the flavonoid content of the extract in terms of rutin equivalent (the standard curve equation: $\mathrm{y}=0.001 \mathrm{x}+$ $\left.0.0588, \mathrm{r}^{2}=0.999\right)$ are given in the table 1 . 


\section{Antioxidant activity}

The results of free radical scavenging capacity of the extract, measured with DPPH assay, and the ratios ( $\left.\mathrm{IC}_{50} \%\right) \mathrm{AA} /\left(\mathrm{IC}_{50} \%\right)$ extract are presented in the table 1. They represent the ascorbic acid equivalent of the extract antioxidant capacity, i.e. the amount of ascorbic acid in milligrams equivalent to one milliliter extract.

\section{Rutin content}

Replicate injections of single standard at different concentrations were used to obtain calibration curve. The UV detection wavelength was set at $350 \mathrm{~nm}$. The equation $y$ $=101.45^{*} \mathrm{x}+6.132(\mathrm{R} 2=0.99)$ with the applied rutin concentration $(\mathrm{x})$ and the area $(\mathrm{y})$ was obtained (Fig. 1). $1 \mathrm{mg} / \mathrm{g}$ of rutin was determined in the extract.

\section{LDs0 of the extract in rat}

The oral and intra-peritoneal $\mathrm{LD}_{50}$ of the extract in rat were $472 \mathrm{mg} / \mathrm{kg}$ and $425 \mathrm{mg} / \mathrm{kg}$ respectively. There was no significant difference between mortality of the male and female rats.

\section{The extract cytotoxicity}

The $\mathrm{IC}_{50}$ values presented in the table 2 show that the extract was different from control group $(\mathrm{P}<0.05)$ and demonstrated cytotoxic activity on all experimental cell lines. Interestingly, the extract showed strong inhibitory activity against ACHN and ASPC1 cell lines after $48 \mathrm{~h}$ and $72 \mathrm{~h}$ followed by $\mathrm{Caco} 2$ and PC12 cells. NIH3T3 cells (as non-neoplastic cells) were less affected by the extract in comparison to other cell lines. This can suggest that the extract may be less toxic for the noncancerous cell lines.

Data expressed as $\mathrm{IC}_{50}$ values $(\mu \mathrm{g} / \mathrm{mL})$ represent means of four determinations. Abbreviations: Caco-2 (colon adenocarcinoma), ACHN (renal adenocarcinoma), ASPC1 (pancreas adenocarcinoma) and PC12 (pheochromocytoma), and NIH/3T3 (Swiss mice embryo fibroblast).

Table 1- The amounts of total phenolic and flavonoid compounds and antioxidant capacity of the extract a

\begin{tabular}{lcc}
\hline $\begin{array}{c}\text { Phenolic compounds } \\
(\mathbf{m g ~ G A} \mathbf{~} / \mathbf{0 . 0 5} \text { g extract })\end{array}$ & $\begin{array}{c}\text { Flavonoids compounds }(\mathbf{m g} \\
\mathbf{R u} / \mathbf{0 . 1} \text { g extract })\end{array}$ & $\begin{array}{c}\text { DPPH radical scavenging activity } \\
\text { IC50\% }(\mathbf{m g} / \mathbf{m L})\end{array}$ \\
\hline $17.84 \pm 0.92$ & $33.35 \pm 1.06$ & $3.57 \pm 0.006$ \\
\hline${ }^{\mathrm{a}}$ Values represent means \pm S.D. of triplicate measurements. \\
${ }^{\mathrm{b}} \mathrm{GA}$, gallic acid. \\
${ }^{\mathrm{c}} \mathrm{Ru}$, rutin.
\end{tabular}


A Toxicological and ...

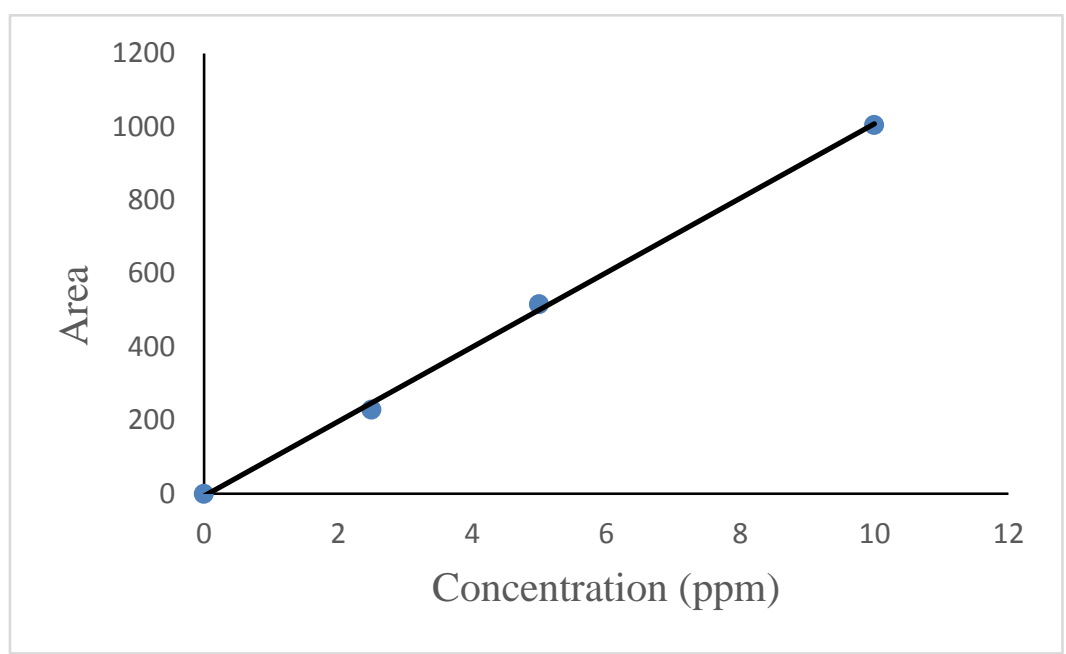

Figure 1- Calibration curve of rutin at $350 \mathrm{~nm}$ wavelength.

Table 2- IC 50 values of the extract effect on various cancerous and non-cancerous cells.

\begin{tabular}{cccc}
\hline Cell lines & \multicolumn{3}{c}{ IC $_{\mathbf{5 0}}$ values $(\boldsymbol{\mu g} / \mathbf{m L})$} \\
\hline Caco2 & $24 \mathrm{~h}$ & $48 \mathrm{~h}$ & $72 \mathrm{~h}$ \\
\cline { 2 - 4 } ACHN & 537.841 & 233.539 & 2.633 \\
ASPC1 & 419.183 & $<1.953$ & 2.192 \\
PC12 & 433.307 & 11.058 & $<1.953$ \\
NIH3T3 & 702.122 & 88.817 & 139.429 \\
control & 418.580 & 280.836 & 249.902 \\
& 100 & 100 & 100 \\
\hline
\end{tabular}

\section{Discussion}

The total phenol, flavonoid and rutin contents as well as antioxidant activity of the extract were measured. The extract $\mathrm{LD}_{50}$ in rat and in vitro cytotoxicity were also evaluated. The $\mathrm{IC}_{50}$ of the extract in the DPPH assay shows that it has low antioxidant activity. $\mathrm{LD}_{50}$ of the extract administered orally and intraperitoneally were $472 \mathrm{mg} / \mathrm{kg}$ and 425 $\mathrm{mg} / \mathrm{kg}$. The oral and intra-peritoneal $\mathrm{LD}_{50}$ of the extract seems to be comparable in this study. The mortality of male and female rats was not significantly different. Substances having $\mathrm{LD}_{50}$ values in the range of $50-500 \mathrm{mg} / \mathrm{kg}$ are regarded as moderately toxic [22]. Thus, the $90 \%$ ethanol extract of the plant is orally and intraperitoneally moderately toxic in the rat. The $\mathrm{LD}_{50}$ tests conducted previously on the E. elaterium fruit are cited as follows. The intra-peritoneal $\mathrm{LD}_{50}$ of the fruit extracted sequentially by chloroform, ethylacetate and $96 \%$ ethanol was $129.2 \mathrm{mg} / \mathrm{kg}$ in mice [7]. The intraperitoneal $\mathrm{LD}_{50}$ of the plant fruit petroleum ether extract was $3.34 \mathrm{~g} / \mathrm{kg}$ in rat [24]. The intravenous $\mathrm{LD}_{50}$ of the fresh fruit juice was $2.5 \mathrm{mg} / \mathrm{kg}$ in rat [25]. Oral $\mathrm{LD}_{50}$ of fruit juice was $61 \mu \mathrm{L}$ in mice [26]. The fruit juice seems to be more toxic than the fruit extracts in the $\mathrm{LD}_{50}$ test. Besides, toxicity of the fruit extract appears to depend on the solvent used for extraction and rout of administration. 
In order to know whether E. elaterium extract is able to affect the proliferation procedures, we followed the growth of 4 cancerous cell lines and 1 non-cancerous cell line in the absence or presence of the extract. We found for all cell lines, the number of cells in the wells were reduced in presence of the plant extract in culture medium. The inhibitory effect on tumor cell proliferation was dosedependent and the E. elaterium extract seems to be a potent inhibitor of tumor cell proliferation. $\mathrm{IC}_{50}$ values below $20 \mu \mathrm{g} / \mathrm{mL}$ represent cytotoxic activity [27]. E. elaterium extract demonstrated cytotoxic effect on $\mathrm{Caco}$, ACHN, ASPC1 with the $\mathrm{IC}_{50}$ values 2.63, 2.192 and $<1.953 \mu \mathrm{g} / \mathrm{mL}$, respectively. The extract showed strong cytotoxicity in ACHN and ASPC1 cell lines, which was followed by Caco 2 and PC12 cells. Non-neoplastic NIH3T3 cells were much less affected by the extract in comparison with the cancerous cells. The extract seems to have considerable selective toxicity on several cancerous cell lines versus noncancerous cells which is an important feature of the extract.

The bioactive compounds and mechanisms mediating the toxicity of the E. elaterium extract were not investigated in the present study. Several studies reported that either E. elaterium or its isolated constituents from this particular species and/or other members of cucurbitaceae family act as natural antiproliferative agents against several cell lines such as gastric, esophageal [5], prostate, melanoma, ovary [28, 29], leukemia [30], glioblastoma [31], breast [28, 32], hepatocytes [33], colon [34], peripheral lymphocytes [35, 36] and pancreatic cancer cells [37]. In line with our results, the E. elaterium seed oil inhibited growth of human colonic adenocarcinoma (HT29) and fibrosarcoma (HT1080) cell lines with the $\mathrm{IC}_{50}$ values $4.86 \mu \mathrm{g} / \mathrm{mL}$ and 4.16 $\mu \mathrm{g} / \mathrm{mL}$ [38]. Our findings in renal adenocarcinoma $\mathrm{ACHN}$ and pancreas adenocarcinoma ASPC1 cell lines were also similar to those of E. elaterium fruit freezedried extract for growth of human gastric carcinoma cell lines $(2.5 \mu \mathrm{g} / \mathrm{mL})$. In addition, we found much higher toxicity in all our cancerous cell lines after $48 \mathrm{~h}$ than that surveyed case of human oesophageal squamous carcinoma cells (500 $\mu \mathrm{g} / \mathrm{mL})$ [5].

Molecular and cellular investigations have shown that cucurbitacins (17 main molecules from cucurbitacin A to T) may affect several intracellular pathways related to the cancer cell proliferation and survival. For instance, they can strongly inhibit the JAK/STAT3 (Janus kinase/signal transducer and activator of transcription 3) signaling pathway mainly via the suppression of STAT3 expression/activation and also are able to disrupt PKB/Akt (protein kinase B also known as Akt) and MAPK/ERK (mitogenactivated protein kinase/extracellular-signalregulated-kinase) pathways $[39,40]$. The molecular mechanisms of action of cucurbitacins in human cancer cells was well reviewed by Lee et al., 2010 [41], though it was discussed that these compounds may proceed their inhibitory properties via varied pathways in different cell lines.

Recently, it was shown that E. elaterium seed oil and cucurbitacin B purified from this species potently suppressed human microvascular endothelial cells angiogenesis, also the authors claimed they have inhibited the adhesion, migration and proliferation of U87 
A Toxicological and ...

glioblastoma cancer cells most probably mediated by $\alpha v \beta 3$ and $\alpha 5 \beta 1$ integrins [30].

To sum up, the present study suggests that the Iran's E. elaterium extract has moderate toxicity when given orally to rat and it has remarkable selective toxicity on cancerous compared to noncancerous cells. These features indicate that Iran's E. elaterium may be a potential source for development of new therapeutic and especially anticancer agents. Additionally, the active constituents and mechanisms responsible for toxicity of the Iran's E. elaterium should be identified.

\section{Conclusion}

The Iran's E. elaterium fruit $90 \%$ alcoholic extract has moderate toxicity when administered orally and intraperitoneally to rat. Moreover, it demonstrates considerable selective toxicity against several cancer cell lines compared to noncancerous cells.

\section{References}

1. Mozaffarian V. Identification of Medicinal and Aromatic Plants of Iran. Farhang Moaser. Iran. 2013, pp: 359-60.

2. Vlachos P, Kanitsakis NN and Kokonas N. Fatal cardiac and renal failure due to Ecballium elaterium (squirting cucumber). J. Toxicol. Clin. Toxicol. 1994; 32 (6): 737-8.

3. Adwan G, Salameh Y and Adwan K. Effect of ethanolic extract of Ecballium elaterium against Staphylococcus aureus and Candida albicans. Asian Pac. J. Trop. Biomed. 2011; 1 (6): 456-60.

4. Attard E and Cuschieri A. Cytotoxicity of cucurbitacin E extracted from Ecballium elaterium in vitro. J. Nat. Remedies. 2004; 4 (2): 137-44.

5. Bohlooli S, Jafari N and Jahed S. Cytotoxic effect of freeze-dried extract of Ecballium elaterium fruit on gastric adenocarcinoma (AGS) and esophageal squamous cell carcinoma (KYSE30) cell lines. J. Gastrointest. Canc. 2012; 43: 579-83.

6. Karimi N, Bohlooli $\mathrm{S}$ and Mazani $\mathrm{M}$. Nanoliposomal formulation of Ecballium elaterium extract: cytotoxic evaluation against human gastric adenocarcinoma (AGS) cell line. Nanomed. Res. J. 2016; 1 (1): 9-14.

7. Agil MH, Risco S, Miro M, Navarro MC, Ocete MA and Jimenez J. Analgesic and antipyretic effects of Ecballium elaterium (L.) A. Richard. extract in rodents. Phytother. Res. 1995; 9: 135-8.

8. Yesilada E, Tanaka S, Tabata M and Sezik E. Antiinflammatory effects of the fruit juice of Ecballium elaterium on edemas in mice. Phytother. Res. 1989; 3 (2): 75-6.

9. Khatib SY, Mahmoud II and Hasan ZA. Effects of crude Ecballium elaterium juice on isolated rabbit heart. Int. J. Pharmacog. 1993; 31 (4): 259-68.

10. El Naggar el MB, Chalupová M, Pražanová G, Parák T, Švajdlenka E, Žemlička $M$ and Suchý P. Hepatoprotective and proapoptotic effect of Ecballium elaterium on $\mathrm{CCl}_{4}$-induced hepatotoxicity in rats. Asian Pac. J. Trop. Biomed. 2015; 8 (7): 526-31.

11. Elayan H, Gharaibeh $M, Z$ meili $S$ and Salhab AS. Effects of Ecballium elaterium juice on serum bilirubin concentration in male rats. Pharm. Biol. 1989; 27 (4): 227-34. 
12. Popov DV, Voinova E, Naidenova EI, Kolarova-Pavlova IK and DimitrovaKonaklieva SD. Antileukemic P-388 action of aqueous plant extracts. CR Acad. Bulg. 1988; 41: 147-9.

13. Uslu C, Karasen RM, Sahin F, Taysi S and Akcay F. Effect of aqueous extracts of Ecballium elaterium rich, in the rabbit model of rhinosinusitis. Int. J. Pediatr. Otorhinolaryngol. 2006; 70 (3): 515-8.

14. Mazokopakis EE, Karefilakis CM and Starakis IK. The safety and efficacy of the fruit juice of Ecballium elaterium in the treatment of acute rhinosinusitis. J. Altern. Complement. Med. 2009; 15 (12): 1273-4.

15. Jaradat N, Jodeh S, Rinno $T$, Kharoof M, Zaid AN and Hannon M. Determination of the presence of phytomelin in Ecballium elaterium to approve its folk uses. Int. J. Pharm. Pharm. Sci. 2012; 4 (2): 233-7.

16. Raikhlin-Eisenkraft $B$ and Bentur Y. Ecballium elaterium (squirting)--remedy or poison? J. Toxicol. Clin. Toxicol. 2000; 38 (3): 305-8.

17. El Sayed ZI and Badr WH. Cucurbitacin glucosides and biological activities of the ethyl acetate fraction from ethanolic extract of Egyptian Ecballium elaterium. J. Appl. Sci. Res. 2012; 8 (2): 1252-8.

18. Obanda M, Owuor PO and Taylor SJ. Flavanol composition and caffeine content of green leaf as quality potential indicators of Kenyan black teas. J. Sci. Food Agric. 1997; 74 (2): 209-15.

19. Marinova $D$, Ribarova $F$ and Atanassova $M$. Total phenolics and total flavonoids in Bulgarian fruits and vegetables. J. Univ. Chem. Technol. Metallurgy. 2005; 40 (3): 255-60.
20. Yuan YV, Bone DE and Carrington MF. Antioxidant activity of dulse (Palmaria palmata) extract evaluated in vitro. Food Chem. 2005; 91 (3): 485-94.

21. Marquis JK. A Guide to General Toxicology. $2^{\text {nd }}$ ed. Karger. Switzerland. 1989, pp: 196-8.

22. Ghosh MN. Fundamentals of Experimental Pharmacology. $6^{\text {th }}$ ed. Hilton \& Company. India. 2008, pp: 112-4.

23. Mosmann T. Rapid colorimetric assay for cellular growth and survival: application to proliferation and cytotoxicity assays. $J$. Immunol. Methods. 1983; 65(1-2):55-63.

24. El-Gengaihi S, Abd El-Hamid SR and Kamel AM. Anti-inflammatory effect of some cucurbitaceous plants. Herba Pol. 2009; 55(4): 11926.

25. Khalil AM and Qaoud KM. Toxicity and partial characterization of Ecballium elaterium fruit juice. Int. J. Pharmacog. 1993; 2: 135-41. 26. Shabbar IMS and Maslat A. Genotoxicity of Ecballium elaterium (L) A Rich Cucurbitaceae fruit juice using micronucleus assay and DNA single strand break techniques. Internet J. Health. 2006; 6 (2): 1-12.

27. Geran RI, Greenberg NH, McDonald MM, Schumacher A and Abbott BJ. Protocols for screening chemical agents and natural products against animal tumors and other biological systems. Cancer Chemother. Rep. 1972; 3 (2): 17-9.

28. Attard E and Cuschieri A. Cytotoxicity of cucurbitacin E extracted from Ecballium elaterium and anticancer agents in vitro. J. Nat. Remedies. 2004; 4 (2): 137 - 44.

29. Attard E, Cuschieri A and Brincat MP. Morphological effects induced by cucurbitacin 
E on ovarian cancer cells in vitro. J. Nat. Remedies. 2005; 5 (1): 70 - 4.

30. Chan KT, Li K, Liu SL, Chu KH, Toh M and Xie WD. Cucurbitacin B inhibits STAT3 and the Raf/MEK/ERK pathway in leukemia cell line K562. Cancer Lett. 2010; 289 (1): 46-52.

31. Touihri-Barakati I, Kallech-Ziri O, Ayadi W, Kovacic H, Hanchi B, Hosni K and Luis J. Cucurbitacin B purified from Ecballium elaterium (L.) A. Rich from Tunisia inhibits a $5 \beta 1$ integrin-mediated adhesion, migration, proliferation of human glioblastoma cell line and angiogenesis. Eur. J. Pharmacol. 2017; 797: 153-61.

32. Tannin-Spitz $\mathrm{T}$, Grossman $\mathrm{S}$, Dovrat $\mathrm{S}$, Gottlieb HE and Bergman M. Growth inhibitory activity of cucurbitacin glucosides isolated from Citrullus colocynthis on human breast cancer cell lines. Biochem. Pharmacol. 2007; 73 (1): 56-67.

33. Takahashi N, Yoshida Y, Sugiura T, Matsuno

K, Fujino A and Yamashita U. Cucurbitacin D isolated from Trichosanthes kirilowii induces apoptosis in human hepatocellular carcinoma cells in vitro. Int. Immunopharmacol. 2009; 9 (4): 50813.

34. Escandell JM, Kaler P, Recio MC, Sasazuki T, Shirasawa S, Augenlicht L, Ríos JL and Klampfer L. Activated kRas protects colon cancer cells from cucurbitacin-induced apoptosis: the role of p53 and p21. Biochem. Pharmacol. 2008; 76 (2): 198 207.

35. Attard E, Brincat MP and Cuschieri, A. Immunomodulatory activity of cucurbitacin $\mathrm{E}$ isolated from Ecballium elaterium. Fitoterapia. 2005; 76 (5): 439-41.

36. Rencüzogullari E, Ila HB, Kayraldiz A, Diler SB, Yavuz A, Arslan M, Funda Kaya F and Topaktas M. The mutagenic and anti-mutagenic effects of Ecballium elaterium fruit juice in human peripheral lymphocytes. Genetika. 2006; 42 (6): 768-72.

37. Thoennissen NH, Iwanski GB, Doan NB, Okamoto R, Lin P, Abbassi S, Song JH, Yin D, Toh M, Xie WD, Said JW and Koeffler HP. Cucurbitacin B induces apoptosis by inhibition of the JAK/STAT pathway and potentiates antiproliferative effects of gemcitabine on pancreatic cancer cells. Cancer Res. 2009; 69 (14): 5876-84.

38. Touihri I, Kallech-Ziri O, Boulila A, Fatnassi S, Marrakchi N, Luis J and Hanchi M. Ecballium elaterium (L.) A. Rich. seed oil: chemical composition and antiproliferative effect on human colonic adenocarcinoma fibrosarcoma cancer cell lines. Arab. J. Chem. 2015; http://dx.doi.org/10.1016/j.arabjc.2015.02.023

39. Chen YW, Chen KH, Huang PI, Chen YC, Chiou GY, Lo WL, Tseng LM, Hsu HS, Chang KW and Chiou SH. Cucurbitacin I suppressed stem-like property and enhanced radiationinduced apoptosis in head and neck squamous carcinoma--derived CD44 (+) ALDH1 (+) cells. Mol. Cancer Ther. 2010; 9 (11): 2879-92.

40. Shi X, Franko B, Frantz C, Amin HM and Lai R. JSI-124 (cucurbitacin I) inhibits Janus kinase3/signal transducer and activator of transcription-3 signalling, downregulates nucleophosminanaplastic lymphoma kinase (ALK), and induces apoptosis in ALK-positive anaplastic large cell lymphoma cells. Br. J. Haematol. 2006; 135 (1): 26-32.

41.Lee DH, Iwanski GB and Thoennissen NH. Cucurbitacin: ancient compound shedding new light on cancer treatment. Scientific World J. 2010; $10,413-8$. 